\title{
Seed germination of Carex lainzii Luceño, E. Rico \& T. Romero: An endemic Spanish endangered species
}

\author{
KAROLINE APARECIDA FELIX RIBEIRO ${ }^{1, \bullet}$, CRISTIAN MADEIRA DE MEDEIROS $^{2}$, \\ JOSÉ ÁNGEL SÁNCHEZ AGUDO ${ }^{1,2}$, JOSÉ SÁNCHEZ SÁNCHEZ ${ }^{1,2}$ \\ ${ }^{1}$ CIALE (Instituto Hispanoluso de Investigaciones Agrarias), Universidad de Salamanca, Salamanca, España. Postal address: Campus de Villamayor, \\ Calle Del Duero nº 12; 37185, Villamayor, Salamanca, España. Tel.: +55-48-991185733`email: karolfr@usal.es \\ ${ }^{2}$ Departamento de Botánica y Fisiología Vegetal, Facultad de Farmacia, Universidad de Salamanca, Salamanca, España. Postal address: Avenida \\ Licenciado Méndez Nieto s/n; 37007, Salamanca, España
}

Manuscript received: 17 January 2019. Revision accepted: 19 February 2019.

\begin{abstract}
Ribeiro KAF, Madeira de Medeiros C, Agudo JAS, Sánchez JS. 2019. Seed germination of Carex lainzii Luceño, E. Rico \& T. Romero: An endemic Spanish endangered species. Biodiversitas 20: xxxx. Strategies to halt the decline of biodiversity include: in-situ and ex-situ conservation, the latter already considered at the global level essential in conservation programs. The results of the germinative responses of Carex lainzii Luceño, E. Rico \& T. Romero (Cyperaceae), an endemic Spanish endangered species, are presented in this work, to different trials carried out in the laboratory with seeds harvested in the two known populations of that community. Treatments with and without $0.2 \%$ potassium nitrate $\left(\mathrm{KNO}_{3}\right)$ were tested for four, six and eight months in cold stratification at $5{ }^{\circ} \mathrm{C}$ in two germination chambers at different temperatures $\left(22 / 10{ }^{\circ} \mathrm{C}\right.$ and $27 / 15{ }^{\circ} \mathrm{C}$ with a photoperiod of $12 / 12$ hours). The results indicate that there is a large difference in germination rates between the two populations. The use of $\mathrm{KNO}_{3}$ did not increase germination rates in any case, but differences were found between periods of cold stratification, with six months being the most effective. On the other hand, the germination rates of both populations remain low $(17.58 \%$ and $2 \%)$ compared to the obtained rate of seed viability. With this first approach to the understanding of the germination requirements of $C$. lainzii, it becomes clear that new essays are needed to obtain better results, in order to effectively implement the protection plans of $C$. lainzii populations.
\end{abstract}

Keywords: Carex lainzii, cold stratification, Iberian Peninsula, potassium nitrate, seed germination

\section{INTRODUCTION}

Human activities have strongly altered and destroyed natural habitats around the world and are seriously threatening global biodiversity at an unprecedented rate (Balmford and Bond 2005; Leemans and De Groot 2003; Secretariat of the Convention on Biological Diversity 2012). Thus, great efforts are needed to halt this decline in biodiversity by employing a wide range of approaches (Conway 1988; Secretariat of the Convention on Biological Diversity 2000; Heywood and Iriondo-Alegría 2003; Guerrant et al. 2004). The main priority is to conserve species in their natural habitat (in-situ); however, ex-situ conservation is becoming increasingly more important and is considered an essential part of global conservation programs, acting as a counterpart to the efforts to conserve plant biodiversity (Guerrant et al. 2004; Secretariat of the Convention on Biological Diversity 2012).

The practical actions of ex-situ conservation and scientific studies developed in Germoplasma Banks specialized in wild plants are fundamental in the current conservation policies. It is generally in these institutions where germinative tests are carried out to elaborate specific protocols for each taxon, that allow to obtain seedlings in an efficient way. This aspect is of fundamental importance in the planning and development of in-situ conservation actions (recovery of habitats and populations) since an optimum use of the seeds available is achieved (IriondoAlegría 2001; Bacchetta et al. 2008; Broadhurst et al. 2008; McGowan et al. 2017).

There is an extensive literature worldwide on the germinative requirements of rare and/or threatened species (e.g., Andreou et al. 2011; Kato and Kadono 2011; Coelho et al. 2012; Del Vecchio et al. 2012; Van der Walt and Witkowski 2017), but in Spain, the country with the highest number of vascular plants among the European and Mediterranean countries and one of the highest rates of threatened species (MAPAMA 2014; Moreno Saiz et al. 2015), such studies are still scarce and therefore necessary (e.g. Navarro and Guitián 2003; Pérez-García 2008; Herranz et al. 2010; Ramos et al. 2010; Narbona et al. 2013; Martinez-Fernandez et al. 2014).

In this way, the main aim of this study was to document the germination efficiency of Carex lainzii Luceño, E. Rico $\&$ T. Romero (Cyperaceae), an Iberian threatened endemism. To this end, different germination tests were used to identify the treatment that produced the best germination rates. In addition, seed quality and viability were studied using tests already proposed in the literature. 


\section{MATERIALS AND METHODS}

\section{Study species}

Carex L., with about to 2000 species, is the largest genus in the Cyperaceae family and is one of the most extensive and ecologically significant genera of vascular plants (Reznicek 1990). Among these species, Carex lainzii can be found, a rhizomatous geophyte endemic to the Iberian Peninsula located in only two autonomous communities of Spain, Castile and Leon, and Aragon. Regarding its conservation status, it is considered a rare species with a very small number of populations due to the transformation of its natural habitat into agricultural land. In addition, in recent years there has been a drastic decrease in the number of individuals of the CastilianLeonese populations; and the extinction of two populations in this same Autonomous Community (Luceño et al. 2009, 2010). As a consequence, this species is in risk of extinction and has been classified as "Endangered" by the criteria of the International Union for the Conservation of Nature (IUCN 2001). It has been also been included on the Red List of Spanish Vascular Plants (Moreno 2008), and it has classified in the category of "in risk of extinction" in the "Decree 63/2007" of Protected Flora of Castile and Leon, (BOCYL 2007). Recommended management measures for this species include: (i) the study and monitoring of populations; (ii) the depositing and storage of seeds in germplasm banks and; iii) germination studies in relation to future population recovery and/or reinforcement plans (Luceño et al. 2009).

Carex lainzii has three known populations, two of which are located in the Autonomous Community of Castile and Leon (Encinas de Esgueva [lat. 41.29; long 4.03] in Valladolid and Cuatro Claros - Prado Largo [lat. 41.76; long -4.14]) in Segovia). The other population is located in the Autonomous Community of Aragon between the provinces of Teruel and Saragossa (Laguna de Gallocanta [lat. 40.9688; long -1.5211]) (Figure 1A; Luceño et al. 2009). The two populations in Castile and Leon are separated approximately $40 \mathrm{~km}$ (Figure 1B). According to Luceño et al. (2009) the population of Cuatro Claros - Prado Largo (population I) is the biggest (150,000 $\mathrm{m}^{2}$ ) and contains around 22,000 individuals, however, our estimates were noticeably lower with approximately 5,000 individual plants. Encinas de Esgueva (population II), has the smallest area $\left(100 \mathrm{~m}^{2}\right)$ and contains about 1,300 individuals (estimates made by direct counting). Furthermore, neither of the two populations is protected by any legal measure that would ensure the conservation of their habitat, either at the national or community levels (Luceño et al. 2009).

\section{Seed collection in Castile and Leon}

This study is part of the Flora conservation strategies developed by the regional administration of Castile and Leon that is why our activities are focused exclusively on the populations located within this territory. Two field trips were organized for collecting the seed: one on July 25, 2014, in the locality of Cuatro Claros-Prado Largo, and the other on August 5, 2014, in the locality of Encinas de
Esgueva. Both populations provided healthy ripe fruits (i.e., utricles) which allowed the germination and viability tests to be carried out in this study. The fruits were collected by hand, at which time the utricles were separated from the spike, and individually deposited and stored in small ventilated plastic bags until further treatments were carried out in the laboratory.

The utricles $(6,000$ and 1,400 approximately; of the populations of Cuatro Claros - Prado Largo and Encinas de Esgueva, respectively), were taken to the laboratory on the same day as the field trip, immediately placed in Petri dishes $(90 \times 14 \mathrm{~mm})$ and left for 15 days at room temperature with the Petri dish half-way open. This step called quarantine is recommended by Bacchetta et al. (2008) being necessary to estimate the phytosanitary status of the material and to make the ripeness of the samples more uniform (i.e., post-ripening).

\section{Germination tests}

The initial germination protocols had already been tested for this species at the Germplasm Bank of the University of Salamanca (BG-USAL) between 2009 and 2011. It was observed that the seeds did not germinate without any previous treatment and thus were in a state of dormancy. Subsequently, the protocols recommended by ISTA (2004), for breaking dormancy, such as immersion in sulfuric acid for 5 and 10 minutes and manual scarification with the use of sandpaper, the use of different temperatures and the alternation of light and darkness in germination chambers were tested. The treatment which produced the best germination rates was as follows: 2 months of cold stratification $\left(5^{\circ} \mathrm{C}\right)$; then the seeds were transferred to a germination chamber with cycles of 12 hours of light and 12 hours of darkness at $30^{\circ} \mathrm{C}$. Since the percentage of seeds that germinated was quite low (30\%), it was necessary to continue testing this protocol (i.e., cold period) as well as other treatments suggested in the literature.

Therefore, in this study additional treatments were carried out on 100 seeds from each of the populations (on Petri plates containing previously sterilized $1 \%$ agar and in four replicates). Treatment with and without potassium nitrate $\left(\mathrm{KNO}_{3}\right)$ at a concentration of $0.2 \%$ was tested after four, six and eight months of cold stratification at $5^{\circ} \mathrm{C}$. Germination took place in two chambers with different temperatures: Temperature I: $22 / 10{ }^{\circ} \mathrm{C}$ and Temperature II (after 4 months of stratification): $35 / 30^{\circ} \mathrm{C}$. Since Temperature II at $35 / 30^{\circ} \mathrm{C}$ had no positive response for either population, after 6 and 8 months of stratification, this temperature was modified to $27 / 15^{\circ} \mathrm{C}$. In both chambers, the high temperature coincided with 12 hours of light and the cold temperature with 12 hours of darkness. The light photoperiod was provided by cool white fluorescent tubes with irradiation of $35 \mu \mathrm{mol} \mathrm{m}^{-2} \mathrm{~s}^{-1}$. The seeds were checked every two days for a period of 60 days and the number of germinated seeds was counted (i.e., with a radicle longer than $2 \mathrm{~mm}$ ). The choice of temperature and the use of $\mathrm{KNO}_{3}$ was based on published studies on other Carex species (Brändel 2005; Brändel and Schütz 2005; Kettenring and Galatowitsch 2007). The concentration of potassium nitrate used was based on the concentration 
recommended by ISTA (2004) and Bacchetta et al. (2008). Finally, due to the low number of seeds collected in the population of Encinas de Esgueva, we choose to have not a control treatment. Furthermore, the importance of cold stratification observed in previous test moved us to combine the application of $\mathrm{KNO}_{3}$ at different temperatures.

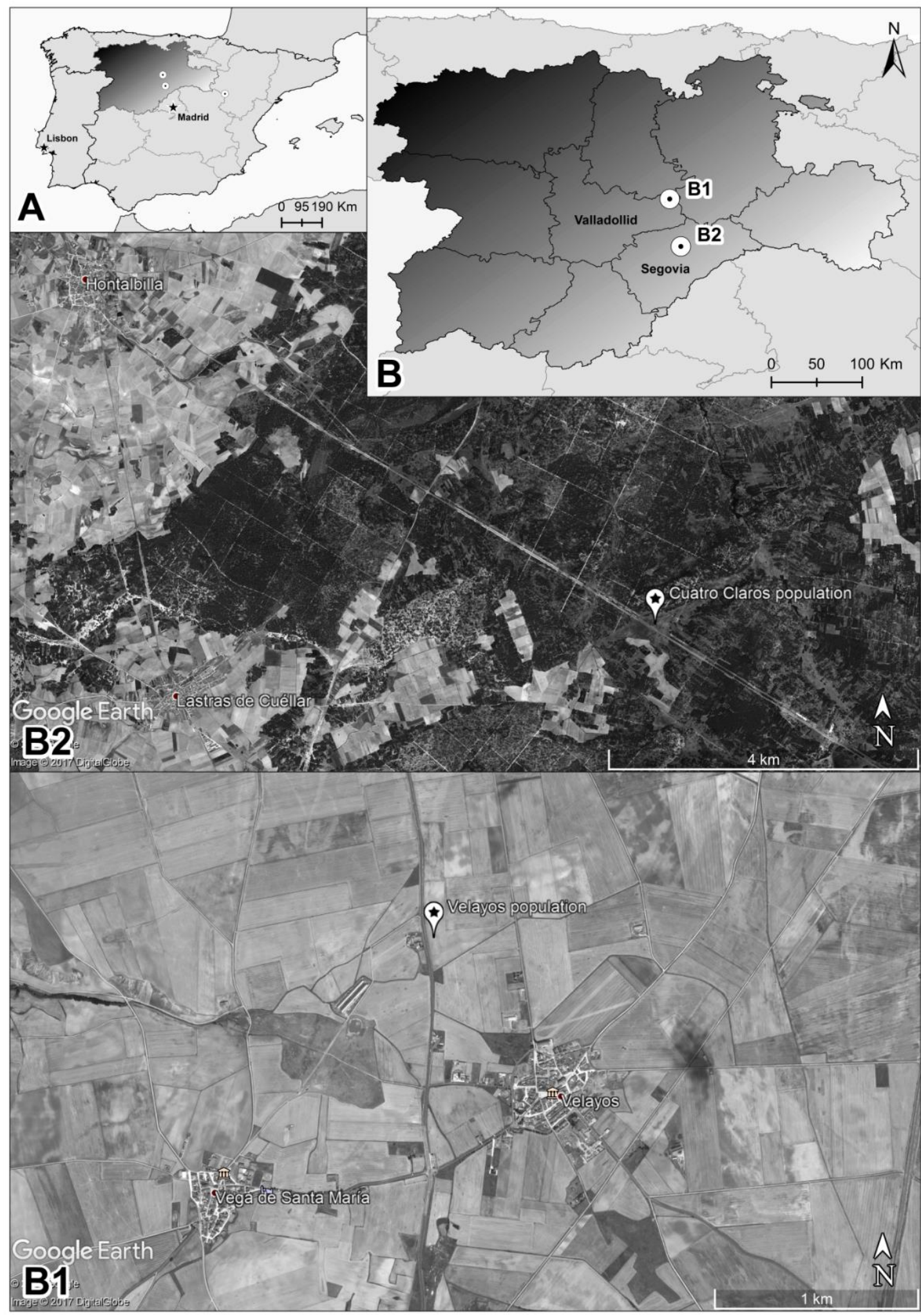

Figure 1. A. Location of the three populations of C. lainzii in the Iberian Peninsula (Autonomous Communities of Castile and Leon detailed- and Aragon). B. Populations of $C$. lainzii in Castile and Leon; B1 = Orthophotograph of the population in the locality of Velayos, province of Valladolid y B2 $=$ Orthophotograph of the population in the locality of Cuatro Claros, province of Segovia 


\section{Viability test}

One of the characteristics of $C$. lainzii seeds observed in this study is the presence of a protective cover that is quite resistant and waterproof, which does not allow the embryo to be removed. Thus, it was not possible to perform the tetrazolium viability test recommended by ISTA (2004). However, the cut test, as recommended by Bacchetta et al. (2008) was carried out and involved analyzing 100 seeds from each population before starting the other types of experiments. This test consists of cutting the seeds in half using a scalpel. Good quality and viable seeds are those that show turgid and healthy tissues, with a typical white color, and the non-viable seeds are those with a dark color, showing defective and damaged tissues.

\section{Statistical analysis}

The final percentages of accumulated germination (mean value \pm standard error) were considered for the germination tests. The Mann-Whitney U-test was applied to analyze the variance between populations, the use of potassium nitrate and the different temperatures (2 categories). One-way ANOVA (Kruskal Wallis - Dunn test for multiple comparisons) was applied to evaluate differences between the cold stratification times. All statistical analysis was performed using the $\mathrm{R}$ program ( $\mathrm{R}$ Core Team 2016).

\section{RESULTS AND DISCUSSION}

\section{Germination tests}

The percentage of germinated seeds observed after 62 days in the germination chambers for each of the tested treatments is shown in Figure 2. According to the global statistical analyzes performed, the following results were obtained: (i) populations - there were very significant differences among the germination rates $(\mathrm{p}<0.0001)$, where the percentage of germination was much higher in population I (Cuatro Claros - Prado Largo). In population II, in addition to having a low germination rate, we observed that the germinated seeds developed poorly, with smaller and less healthy tissues; (ii) the use of potassium nitrate - there were no significant differences for the germination rate between the treatments with and without $\mathrm{KNO}_{3}(\mathrm{p}=0.56)$; (iii) cold stratification - differences were found among the different cold treatments $(\mathrm{p}=0.002)$ and as shown in Table 1, the results obtained after 6 months of stratification showed a significant difference in the rate of germination to those observed after 4 months $(\mathrm{p}=0.0061)$, and after 8 months $(p=0.0025)$. In addition, there was no significant difference between 4 and 8 months of stratification $(p=1.000)$. Since the 6-month stratification period according to statistical data was the most effective at breaking seed dormancy and increased the rate of germination. Two Mann-Whitney U-test were applied to test the variances and was used to verify any difference between the two temperatures tested (Temperature I: 22/10 ${ }^{\circ} \mathrm{C}$ and Temperature II: $27 / 15^{\circ} \mathrm{C}$ ). The results indicated that there was no difference between these temperatures ( $\mathrm{p}=$ 0.198). On the other hand, the best results were observed for Temperature II (19.95\% germination versus $12.44 \%$ temperature I) (Table 1).

\section{Viability test}

The results of the cut test performed for each population can be seen in Table 2. The difference in the quality of the seed from the population of $C$. lainzii located in Cuatro Claros - Prado Largo (population I) with respect to the population located in Encinas de Esgueva (population II) can clearly be seen. The material collected from population I had less empty seeds ( $90 \%$ were potentially viable) as compared to the seed collected from population II $(25 \%$ were potentially viable). In fact, when comparing these values with the best results obtained for the germination rates of population I (34\% after 6 months of cold stratification at temperature II without the use of potassium nitrate) and population II (11\% after 6 months of cold stratification at temperature II without the use of potassium nitrate), it can be seen that these values do not coincide with the percentage of potentially viable seeds for either population.

Table 1. Final percentage of germination and results of statistical analyzes of comparisons between: populations, use of $\mathrm{KNO}_{3}$, periods of cold stratification, and temperatures tested at 6 months of stratification. W indicates values of Mann-Whitney and $p$ indicates the significance level

\begin{tabular}{|c|c|c|}
\hline Population & \multicolumn{2}{|c|}{ Germination $(\% \pm \mathrm{SE})$} \\
\hline Cuatro Claros & $17.64 \pm 14.51$ & \\
\hline Encinas de Esgueva & $2.18 \pm 3.68$ & \\
\hline U Table & $\mathrm{W}$ & $\mathrm{p}$ \\
\hline Population & 1011 & $* * *$ \\
\hline $\mathrm{KNO}_{3}$ & \multicolumn{2}{|c|}{ Germination $(\% \pm \mathrm{SE})$} \\
\hline Without & \multicolumn{2}{|l|}{$11.53 \pm 13.84$} \\
\hline With & \multicolumn{2}{|l|}{$9.07 \pm 12.75$} \\
\hline U Table & $\mathrm{W}$ & $\mathrm{p}$ \\
\hline $\mathrm{KNO}_{3}$ & 696.5 & 0.5608 \\
\hline Cold estrat. & \multicolumn{2}{|c|}{ Germination $(\% \pm \mathrm{SE})$} \\
\hline 4 months & \multicolumn{2}{|l|}{$6.50 \pm 11.27$} \\
\hline 6 months & \multicolumn{2}{|l|}{$19.67 \pm 14.13$} \\
\hline 8 months & \multicolumn{2}{|l|}{$5.74 \pm 10.03$} \\
\hline Anova Table & $\mathrm{gl}$ & $\mathrm{p}$ \\
\hline Cold estratification & 7.163 & $0.002 *$ \\
\hline $\begin{array}{l}\text { Kruskal Wallis- Dunn test } \\
\text { (multiple comparisons) }\end{array}$ & \multicolumn{2}{|l|}{$\mathrm{p}$} \\
\hline $4 \times 6$ months & \multicolumn{2}{|l|}{$0.0061 *$} \\
\hline $4 \times 8$ months & \multicolumn{2}{|l|}{1.000} \\
\hline $6 \times 8$ months & \multicolumn{2}{|l|}{$0.0025^{*}$} \\
\hline Temp. (6 months cold estrat.) & \multicolumn{2}{|c|}{ Germination $(\% \pm \mathrm{SE})$} \\
\hline Temp.I $\left(22 / 10^{\circ} \mathrm{C}\right)$ & \multicolumn{2}{|l|}{$18.71 \pm 15.25$} \\
\hline Temp.II $\left(27 / 15^{\circ} \mathrm{C}\right)$ & \multicolumn{2}{|l|}{$20.39 \pm 13.88$} \\
\hline U Table & $\mathrm{W}$ & $\mathrm{p}$ \\
\hline Temperature & 49 & 0.19 \\
\hline
\end{tabular}

Table 2. Percentage of the cut test carried out with Carex lainzii seeds from the two populations of Castile and Leon (population of Encinas de Esgueva - province of Valladolid; and population of Cuatro Claros-Prado Largo - Province of Segovia)

\begin{tabular}{lcccc}
\hline \multicolumn{5}{c}{ Viability } \\
\hline & Viable & Nonviable & Empty & Total \\
\hline Cuatro Claros & 65 & 25 & 10 & 100 \\
Encinas de Esgueva & 23 & 2 & 75 & 100 \\
\hline
\end{tabular}



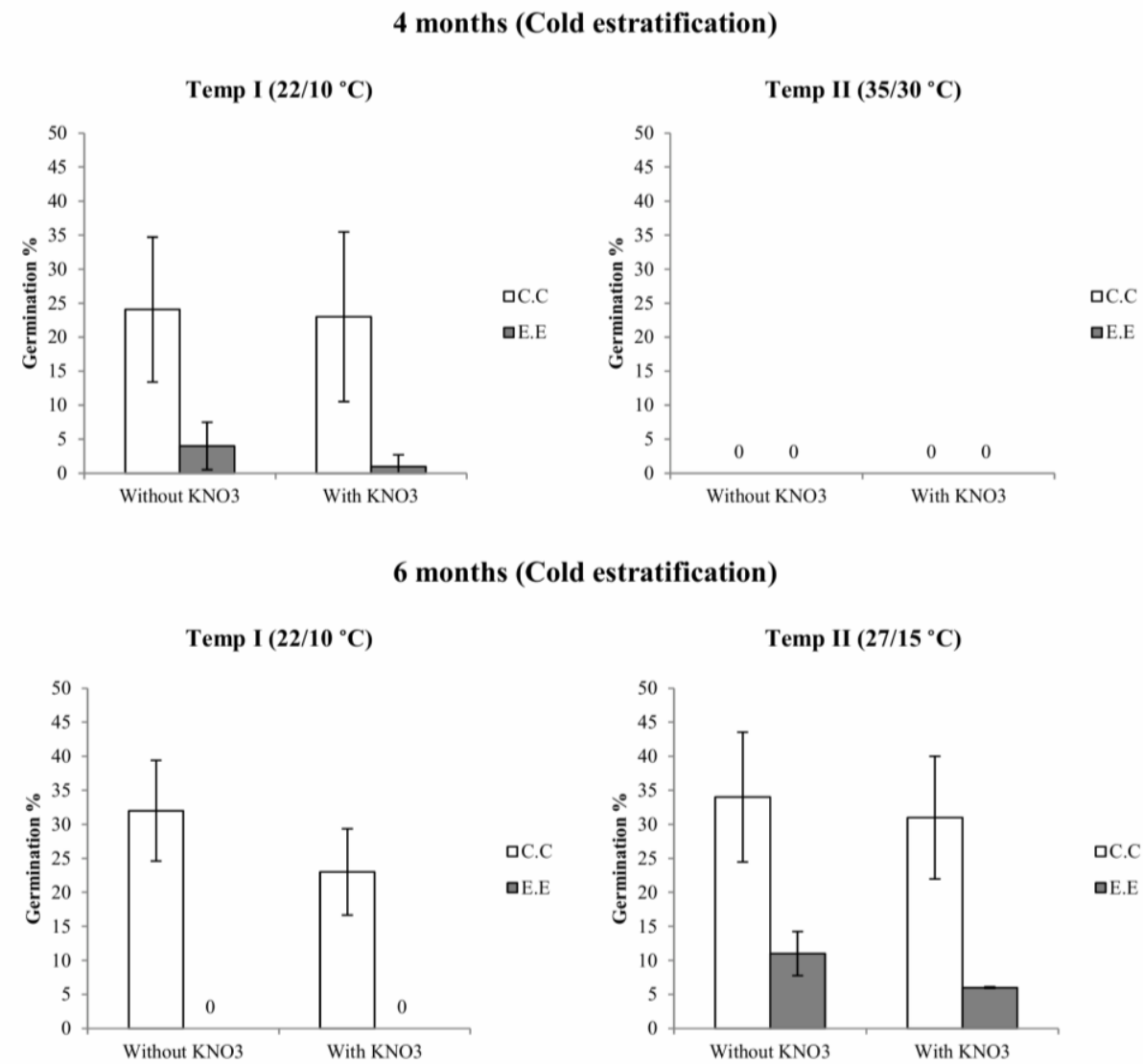

8 months (Cold estratification)

Temp I $\left(22 / 10{ }^{\circ} \mathrm{C}\right)$

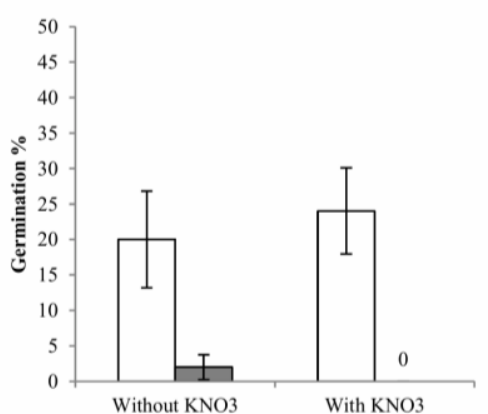

Temp II $\left(27 / 15^{\circ} \mathrm{C}\right)$

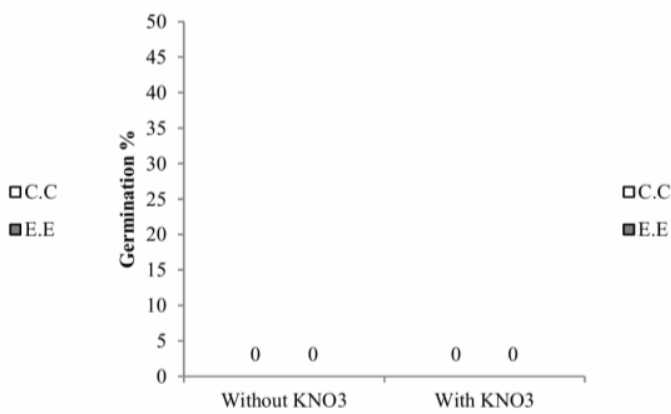

Figure 2. Final percentage of germination $( \pm \mathrm{SE})$ for each treatment tested with seeds of two populations of Carex lainzii (C.C $=$ Cuatro Claros - Prado Lardo, Segovia; E.E = Encinas de Esgueva, Valladolid). Results after 62 days of incubation

\section{Discussion}

In nature, seed dormancy is a mechanism that allows a plant to survive in a particular environment, avoiding germination during periods with unfavorable conditions for seedling survival (Baskin and Baskin 1998; Bacchetta et al. 2008). Some authors have highlighted the effectiveness of cold stratification to break the seed dormancy of annual and perennial plants in temperate regions (e.g., Schütz and Rave 1999; Probert 2000; Baskin and Baskin 2003), since this type of stratification helps to ensure that germination occurs in spring or early summer (Probert 2000).
After comparing our results with other studies carried out on Carex species, we can conclude that there exists a wide range of varying results in the literature. Brändel and Schütz (2005) for instance, achieved their best results after 3 months of stratification at $5^{\circ} \mathrm{C}$ and germinating $C$. pendula and $C$. remote seeds at the temperature cycle of $15 / 5{ }^{\circ} \mathrm{C}$. Additionally, Kettenring and Galatowitsch (2007) analyzed 12 species of Carex and obtained different results for each species. These authors used five diurnal temperature regimes in different periods of stratification being the temperature cycles of $22 / 8^{\circ} \mathrm{C}$ and $35 / 30^{\circ} \mathrm{C}$ the 
most similar to those tested in this study. However, the study by Schütz and Rave (1999) showed results similar to ours, where the best germination rates for 28 out of 34 species were achieved using a single period of 6 months of cold stratification at $4^{\circ} \mathrm{C}$ with temperature cycle of $22 / 10^{\circ} \mathrm{C}$ and photoperiod of $12 / 12$ hours.

Comparative studies on a number of species living in a particular habitat or at a site that covers various habitats have shown that germination patterns are due on one hand to the characteristics of the habitat, and on the other a function of the geographical range and plant life form (Washitani and Masuda 1990; Baskin and Baskin 2003). Due to a large number of species within this genus, Carex can be found in a wide range of habitats such as dry grasslands, dry and mesic forests, heathlands, dunes; even rocky outcrops can house one or several species of Carex (Schütz 2000). This could explain the wide range of different types of protocols that are used to study the different Carex species.

Thus, the lack of germination that was observed in the present study using the temperature cycle of $35 / 30^{\circ} \mathrm{C}$ after 4 months of cold may be due to the fact that the Carex species that presented the best germination rates using these conditions were from warmer regions and habitats in North America. These particular conditions, which were also used in this study, were taken from the study by Kettenring and Galatowitsch (2007). Consequently, the decision taken to modify the temperature in the treatments carried out later on in the study was due to the fact that $C$. lainzii is a species in danger of extinction and therefore the seeds could not be wasted.

The low germination rate of $C$. lainzii in comparison with the data obtained from the viability test, the discrepancy observed may be that cold stratification cannot break seed dormancy alone, which is supported by the results observed for the three different periods of cold stratification used. Furthermore, the use of plant hormones and potassium nitrate has been shown in several studies to be an important factor for promoting and/or increasing the germination rates of various species (Dissanayake et al. 2010; Dong et al. 2012; Hu et al. 2012; Duclos et al. 2013).

In contrast to the study by Brändel (2005), who achieved an increase in the breaking of dormancy of $C$. pendula seeds and consequently a higher germination rate by combining different stratification treatments with the use of potassium nitrate, our results did not indicate significant differences between the treatments with and without the use of potassium nitrate.

In relation to the low germination rates, and of course the poor health of the seedlings of population II (Encinas de Esgueva) as compared to population I (Cuatro Claros), this might be explained, in part, to the late seeds collection which took place on August 5. This species usually bear fruit between May and July (Luceño et al. 2010). According to Bacchetta et al. (2008), seed collection is a key factor in germination studies and ex-situ conservation, since seed collection should take place when each species is at its optimum maturation stage. Late collection may result in the loss of material due to natural seed dispersion, the poor quality of the material due to animal predation or the natural loss vigor with respect to germination.

However, it was observed in the cut test that $75 \%$ of seeds of the Encinas de Esguevas population were empty, and not inviable owing to other factors. One possible justification might be that in the case of a population with a very small habitat $\left(100 \mathrm{~m}^{2}\right)$, the pressures that threaten the species cause a greater impact on the reproduction of the species. The use of this area for leisure and sports activities is one of the main factors that threaten this particular population (its habitat is located in what is currently a football field with very low activity). Other factors include the management of aquatic or riverside vegetation used for drainage purposes and the management of water levels (the population is surrounded by a channel that prevents flooding). Additionally, there is a well from which water is extracted that consequently lowers the water table (Luceño et al. 2009).

Moreover, inbreeding depression may be occurring due to the low number of individuals, and the lack of gene flow with the other population in Cuatro Claros located $40 \mathrm{~km}$ away. Inbreeding refers to cross-breeding between related individuals which causes an increase in homozygosity. The cost of fitness that is associated with inbreeding could be caused by deleterious alleles (Neaves et al. 2015). Many populations of endangered species are typically small and isolated, characteristics that often make them more prone to low genetic diversity. This, in turn, can reduce their reproductive capacity (Frankham et al. 2010).

Studies on the orchid Gymnadenia conopsea (L.) R.Br. carried out by Sletvold et al. (2012), and the orchid species Serapias vomeracea (Burm. fil.) Briq., S. cordigera L. and $S$. parviflora Parl. by Bellusci et al. (2009) revealed that inbreeding depression is highly correlated with low seed production, embryoless seeds, and low seed germination. However, further research in this field with regard to $C$. lainzii is needed to draw more concrete conclusions. This would involve a population follow-up for documenting seed quality over several years, as well as a detailed molecular study of the genetic variability of this species.

In conclusion, our essays have confirmed a low germinative capacity for the Castilian-Leonese populations of $C$. lainzii in all the treatments tested. The high interpopulation variability, with even lower germination rates for the population of Encinas de Esgueva, Valladolid (not exceeding more than $11 \%$ germination) associated with low seed viability documented in our study, brings out the urgent need to carry out conservation strategies for this species. These actions should complement ex-situ strategies (long-term conservation of germplasm that can provide live material in case of possible extinction, and also studies of genetic variability); and in-situ (plans for population reinforcement, experimental introductions, and reintroductions). Annual monitoring of populations for census and material collection aimed at increasing the genetic variability of material stored in Germplasm Banks are recommended. We also recommend the isolation of populations using physical barriers (e.g. fences), jointly to information signs in order to raise awareness among local people. For the most threatened population, Encinas de Esgueva, the physical barrier should include the 
surrounding habitat within a radius of approximately $50 \mathrm{~m}^{2}$ and the area occupied by the population $\left(100 \mathrm{~m}^{2}\right)$. So, the external disturbances, especially anthropic ones, can be minimized by guaranteeing self-regulation and increasing numbers of individuals of $C$. lainzii. Finally, new studies including the Aragonese population are necessary in order to better understand the germinative requirements of this threatened species.

\section{ACKNOWLEDGEMENTS}

The first author would like to thank Coordenação de Aperfeiçoamento de Pessoal de Nivel Superior (CAPES; process $n^{\circ}$ 8928/13-4) for the awarding of a Ph.D's grant. To all the research team of the group of "Palynology and Plant Conservation" of the Hispanoluso Agricultural Research Centre (CIALE) for their contributions.

\section{REFERENCES}

Andreou M, Delipetrou P, Kadis C et al. 2011. An integrated approach for the conservation of threatened plants: The case of Arabis kennedyae (Brassicaceae). Acta Oecologica 37: 239-248. DOI: 10.1016/J.ACTAO.2011.02.007

Bacchetta G, Fenu G, Mattana E et al. 2008. Conservación ex-situ de plantas silvestres. Jardín Botánico Atlántico, Gijón.

Balmford A, Bond W. 2005. Trends in the state of nature and their implications for human well-being. Ecol Lett 8: 1218-1234. DOI: 10.1111/j.1461-0248.2005.00814.x

Baskin JM, Baskin CC. 2003. Classification, biogeography, and phylogenetic relationships of seed dormancy. In: Smith R, Dickie J, Linington S (eds.). Seed Conservation: Turning Science into Practice. Royal Botanic Gardens, Kew.

Baskin JM, Baskin CC. 1998. Seeds: Ecology, Biogeography, and, Evolution of Dormancy and Germination. Elsevier, Lexington.

BOCYL. 2007. DECRETO 63/2007, de 14 de junio, por el que se crean el Catálogo de Flora Protegida de Castilla y León y la figura de protección denominada Microrreserva de Flora. Boletín de Castilla y León 119: 13197-13204

Brändel M. 2005. The effect of stratification temperatures on the level of dormancy in primary and secondary dormant seeds of two Carex species. Plant Ecol 178: 163-169. DOI: 10.1007/s11258-004-3037-y

Brändel M, Schütz W. 2005. Temperature effects on dormancy levels and germination in temperate forest sedges (Carex). Plant Ecol 176: 245 261. DOI: $10.1007 / \mathrm{s} 11258-004-0117-y$

Broadhurst LM, Lowe A, Coates DJ et al. 2008. Seed supply for broadscale restoration: maximizing evolutionary potential. Evol Appl 1: 587-597.

Coelho N, Gonçalves S, González-Benito ME, Romano A. 2012 Germination and cryopreservation tolerance of seeds from the rare aromatic species Thymus lotocephalus. Sci Hortic 145: 84-86. DOI 10.1016/J.SCIENTA.2012.07.031

Conway W. 1988. Can technology aid species preservation. In: Wilson EO, Peter FM (eds.). Biodiversity. National Forum on Biodiversity, New York.

Del Vecchio S, Mattana E, Acosta ATR, Bacchetta G. 2012. Seed germination responses to varying environmental conditions and provenances in Crucianella maritima L., a threatened coastal species. C R Biol 335: 26-31. DOI: 10.1016/j.crvi.2011.10.004

Frankham R. 2010. Challenges and opportunities of genetic approaches to biological conservation. Biol Conserv 143: 1919-1927. DOI: 10.1016/J.BIOCON.2010.05.011

Guerrant EO, Fiedler PL, Havens K, Maunder M. 2004. Revised genetic sampling guidelines for conservation collections of rare and endangered plants. In: Guerrant EO, Havens K, Maunder M. (eds.) Ex-situ Plant Conservation: Supporting Species Survival in the Wild. Island Press, Washington, DC.
Herranz JM, Ferrandis P, Martínez-Duro E. 2010. Seed germination ecology of the threatened endemic Iberian Delphinium fissum subsp. sordidum (Ranunculaceae). Plant Ecol 211: 89-106. DOI: 10.1007/s11258-010-9775-0

Heywood VH, Iriondo-Alegría JM. 2003. Plant conservation: old problems, new perspectives. Biol Conserv 113: 321-335. DOI: 10.1016/S0006-3207(03)00121-6

Hoban S, Schlarbaum S. 2014. Optimal sampling of seeds from plant populations for ex-situ conservation of genetic biodiversity, considering realistic population structure. Biol Conserv 177: 90-99. DOI: 10.1016/J.BIOCON.2014.06.014

Iriondo-Alegría JM. 2001. Conservación de germoplasma de especies raras y amenazadas (Revisión). Investig Agrar Prod Veg 16: 5-24.

ISTA. 2004. International Rules for Seed Testing. The International Seed Testing Association, Bassersdorf.

IUCN. 2001. Categorias y criterios de la Lista Roja de la UICN, versión 3.1. Unión Internacional para la Conservación de la Naturaleza de los Recursos Naturales Comisión de Supervivencia de Especies de la UICN (en Español), Gland, Switzerland and Cambridge.

Kato R, Kadono Y. 2011. Seed germination traits of Trapella sinensis (Trapellaceae), an endangered aquatic plant in Japan: Conservation implications. Aquat Bot 95: 258-261. DOI: 10.1016/J.AQUABOT.2011.08.002

Kettenring KM, Galatowitsch SM. 2007. Tools for Carex revegetation in freshwater wetlands: understanding dormancy loss and germination temperature requirements. Plant Ecol 193: 157-169. DOI: $10.1007 / \mathrm{s} 11258-006-9255-8$

Leemans R, De Groot RS. 2003. Millennium Ecosystem Assessment: Ecosystems and Human Well-Being: A Framework for Assessment. World Resources Institute, Washington, DC.

Luceño M, Escudero M, González M. 2009. Fichas con recopilación de información sobre las especies incluidas en el Decreto 63/2007. Carex lainzii Luceño, E. Rico \& T. Romero. Departamento de Biología Molecular e Ingeniaría Bioquímica, Universidad Pablo de Olavide, Sevilla.

Luceño M, Escudero M, Jiménez Mejías P. 2010. Carex L. In: Castroviejo S, Aedo C, Laínz M, Muñoz Garmendia F, Nieto Feliner G, Paiva J, Benedí C. (eds.). Flora Iberica 17. Real Jardín Botánico, CSIC, Madrid.

MAPAMA. 2014. Quinto Informe sobre la Diversidad Biológica. Ministerio de Agricultura y Pesca, Alimentación y Medio Ambiente, Madrid. https: //www.cbd.int/doc/world/es/es-nr-05-es.pdf.

Martinez-Fernandez V, Martínez-García F, Garcia FP. 2014. Census, reproductive biology, and germination of Astragalus gines-lopezii (Fabaceae), a narrow and endangered endemic species of SW Spain. Turk J Bot 38: 686-695.

McGowan PJK, Traylor-Holzer K, Leus K. 2017. IUCN Guidelines for determining When and how ex-situ management should be used in species conservation. Conserv Lett 10: 361-366. DOI: $10.1111 /$ conl. 12285

Moreno JC (ed.). 2008. Lista Roja 2008 de la flora vascular española. Dirección General de Medio Natural y Política Forestal. Ministerio de Medio Ambiente y Medio Rural y Marino, y Sociedad Española de Biología de la Conservación, Madrid.

Moreno JC, Lozano FD, Gómez MM, Baudet ÁB. 2015. Application of the Red List Index for conservation assessment of Spanish vascular plants. Conserv Biol 29: 910-919. DOI: 10.1111/cobi.12437

Narbona E, Delgado A, Encina F, Miguez M, Buide M.L. 2013. Seed germination and seedling establishment of the rare Carex helodes Link depend on the proximity to water. Aquat Bot 110: 55-60. DOI: 10.1016/J.AQUABOT.2013.05.005

Navarro L, Guitián J. 2003. Seed germination and seedling survival of two threatened endemic species of the northwest Iberian peninsula. Biol Conserv 109: 313-320. DOI: 10.1016/S0006-3207(02)00151-9

Pérez-García F. 2008. Effect of cryopreservation, gibberellic acid and mechanical scarification on the seed germination of eight endemic species from the Canary Islands. Seed Sci Technol 36: 237-242.

Probert RJ. 2000. The role of temperature in the regulation of seed dormancy and germination. Seeds Ecol Regen Plant Comm 2: 261292.

R Core Team. 2016. R: A language and environment for statistical computing. R Foundation for Statistical Computing, Vienna. http: //www.r-project.org/.

Ramos S, Rincón S, Vázquez FM. 2010. Distribution and germination characteristics of Astragalus gines-lopezii: an endangered species. Ann Bot Fenn 47: 330-336. 
Reznicek AA. 1990. Evolution in sedges (Carex, Cyperaceae). Can J Bot 68: 1409-1432. DOI: $10.1139 / \mathrm{b} 90-180$

Schütz W, Rave G. 1999. The effect of cold stratification and light on the seed germination of temperate sedges (Carex) from various habitats and implications for regenerative strategies. Plant Ecol 144: 215-230. DOI: $10.1023 / \mathrm{a}: 1009892004730$

Secretariat of the Convention on Biological Diversity. 2012. The Global Strategy for Plant Conservation: 2011-2020. Botanic Gardens Conservation International, Richmond.
Secretariat of the Convention on Biological Diversity. 2000. Sustaining Life on Earth: How the Convention on Biological Diversity promotes nature and human well-being. Convention on Biological Diversity (CBD), Montreal.

Van der Walt K, Witkowski ETF. 2017. Seed viability, germination and seedling emergence of the critically endangered stem succulent, Adenium swazicum, in South Africa. S A J Bot 109: 237-245. DOI: 10.1016/J.SAJB.2017.01.011 